\title{
Comparative Adsorption Mechanism of Rice Straw Activated Carbon Activated with $\mathrm{NaOH}$ and $\mathrm{KOH}$
}

(Perbandingan Mekanisma Penjerapan Karbon Teraktif Jerami Padi yang Diaktif dengan NaOH dan KOH)

\author{
Mohamad Jani SaAd, Mohd Shaiful Sajab, WAn NaZri Wan Busu, Sufian Misran, Sarani Zakaria, \\ Siew Xian Chin \& Chin Hua Chia*
}

\begin{abstract}
Activated carbon (AC) was produced from rice straw via a two-step method. Potassium hydroxide (KOH) and sodium hydroxide (NaOH) were used as activating agent. The activated carbon (AC) samples were used as adsorbent to remove methylene blue (MB) from aqueous solution. Characterizations using a scanning electron microscope (SEM), BrunauerEmmett-Teller surface area (BET), and Fourier transform infrared (FTIR) spectroscopy were performed on the samples before the MB adsorption experiments. The adsorption isotherms and kinetics analyses were carried out under different conditions of $\mathrm{pH}$, temperature, and $\mathrm{MB}$ concentration to study the adsorption efficiency of the samples against the MB solution. The adsorption kinetics of both activated carbon samples followed the pseudo-second-order model. The adsorption capacity of the $\mathrm{KOH}$ rice straw activated carbon towards MB achieved a maximum adsorption 588 $\mathrm{mg} / \mathrm{g}$ as compared to $232 \mathrm{mg} / \mathrm{g}$ of the $\mathrm{NaOH}$ rice straw activated carbon. The intraparticle diffusion model indicated that the adsorption process of the activated carbon samples toward MB included the external mass transfer and diffusion of MB molecules into the adsorbents. Adsorption isotherm results for MB on the activated carbon samples fit the Langmuir isotherm, suggesting monolayer adsorption during the adsorption process.
\end{abstract}

Keywords: Activated carbon; adsorption; adsorption isotherm; methylene blue; rice straw

\section{ABSTRAK}

Karbon teraktif dihasilkan daripada jerami padi melalui kaedah 2 peringkat. Potasium hidroksida (KOH) dan natrium hidroksida (NaOH) telah digunakan sebagai agen aktivasi. Sampel karbon teraktif (AC) telah digunakan sebagai bahan penjerap untuk menyingkirkan metilena biru (MB) daripada larutan akuas. Pencirian terhadap sampel karbon teraktif menggunakan mikroskopi penskanan elektron (SEM), luas permukaan Brunauer-Emmett-Teller (BET) dan spektroskopi transformasi Fourier inframerah (FTIR) telah dijalankan sebelum uji kaji penjerapan MB. Analisis kinetik dan isoterma penjerapan dijalankan pada pelbagai keadaan $\mathrm{pH}$, suhu dan kepekatan MB bagi mengkaji kecekapan penjerapan sampel terhadap larutan MB. Penjerapan kinetik untuk kedua-dua sampel karbon teraktif menuruti model tertib pseudo kedua. Kapasiti penjerapan karbon teraktif jerami padi KOH terhadap MB telah mencapai penjerapan maksimum sebanyak $588 \mathrm{mg} / \mathrm{g}$ berbanding karbon teraktif jerami padi NaOH iaitu $232 \mathrm{mg} / \mathrm{g}$. Model peresapan intrapartikel bagi proses penjerapan sampel karbon teraktif terhadap MB merangkumi pemindahan berat luaran dan resapan molekul MB terhadap karbon teraktif. Keputusan isoterma penjerapan mengikuti isoterma Langmuir, ia menunjukkan penjerapan lapisan mono berlaku semasa proses penjerapan.

Kata kunci: Isoterma penjerapan; jerami padi; karbon teraktif; metilena biru; penjerapan

\section{INTRODUCTION}

Water is of fundamental importance to life on earth. Agriculture, human consumption, industry, and recreation all need adequate supplies of water (Sharma \& Bhattacharya 2017). Urban and industrial activities have polluted the environment, and pollution has become a crucial problem that needs to be tackled or at least controlled (Sulyman et al. 2017). Due to technological and industrial growth, freshwater resources around the world are threatened. One-sixth of the world's population has suffered from the depletion of available freshwater (Elimelech 2006). Developed nations suffer most from chemical discharge 
problems, whereas developing nations face problems from agricultural sources. Providing clean and safe water for all is a tough task (Sharma \& Bhattacharya 2017).

Dyes are mostly used in the paper, textile, leather, cosmetics, wool, and printing industries. Wastewater polluted with dye reduces the dissolved oxygen content in water and hinders sunlight from penetrating the water. Furthermore, some of the dyes are carcinogenic or poisonous to human beings (Bhattacharya \& Sharma 2005). Therefore, the dyes need to be removed from wastewater before its discharge into water sources. Methylene blue (MB), an aromatic heterocyclic compound, has been used extensively, especially in the textile industry. However, wastewater polluted with MB has negative impacts on aquatic ecosystems, flora, and fauna (Ghosh \& Bhattacharyya 2002; Guo et al. 2014). In humans, it may cause nausea, vomiting, profuse sweating, mental confusion, and methemoglobinemia (Ghosh \& Bhattacharyya 2002; Tan et al. 2008). Researchers are challenged to find appropriate and environmentally friendly treatment techniques to remove pollutants from water resources; various techniques have been introduced, including irradiation, coagulation, ozonation, flocculation, ion exchange, electrokinetic treatment, electrochemical destruction, membrane filtration, photocatalytic oxidation, and adsorption (Danish et al. 2014). The adsorption process is a popular technique because it is inexpensive, feasible, and easy to use for the removal of dyes from water (Bansal \& Goyal 2005; Ghosh \& Bhattacharyya 2002; Ho \& Mckay 2003; Sun \& Yang 2003; Tan et al. 2008). Activated carbon (AC) is mostly used for the adsorption process to remove dyes from polluted water because of its excellent adsorption ability (Bansal \& Goyal 2005). However, due to its high cost, some researchers have investigated how to produce cheaper and equally effective adsorbents (Banat et al. 1996; Crini 2006; El-Maghraby \& Deeb 2018; Ghosh \& Bhattacharyya 2002; McMullan et al. 2001; Mohan et al. 2002; Pearce et al. 2003; Rafatullah et al. 2010; Tan et al. 2008). AC can be produced from agriculture waste such as paddy straw (Gao et al. 2011), paddy husk (Muniandy et al. 2014), coconut waste (Iqbaldin et al. 2013), peanut shell (Wu et al. 2013), palm kernel shell (Rugayah et al. 2014), walnut shell (Yu et al. 2014), corn cob (Song et al. 2013), and sugarcane (Sreńscek-Nazzal et al. 2013), among other materials.

Rice has been a staple food for Malaysia and one waste product from the paddy industry is the rice straw produced during the paddy cultivation process. More than 3 million tons of rice straw are produced in Malaysia from $680,000+$ acres of paddy fields every year (Aznie \& Mohd Zainol 2014). Some of the rice straw is used for soil enrichment, but most are left in the field or burned, causing air pollution, which is not good for the environment. Thus, it would be beneficial to use the paddy straw waste to produce a valuable product like AC.

$A C$ can be produced via physical (steam, air, or $\mathrm{CO} 2)$ or chemical $(\mathrm{ZnCl} 2$ or $\mathrm{KOH})$ activation or a combination of both. Chemical activation is preferable over physical activation due to a high carbon yield and the AC produced has a high specific surface area and good pore development (Hirunpraditkoon et al. 2011; Patil \& Kulkarni 2012). In the past few years, potassium salts, such as $\mathrm{KOH}$ and $\mathrm{K} 2 \mathrm{CO} 3$, have been widely used in the making of low-cost AC. AC produced from $\mathrm{KOH}$ activation is highly microporous compared to activation with $\mathrm{ZnCl} 2$ or H3PO4 (Abechi et al. 2013; Ocholi 2013; Okman et al. 2014). Furthermore, KOH also promotes the specific surface area and the formation of $\mathrm{OH}$ functional groups on the carbon surface (Viswanathan et al. 2009).

In the present study, the $\mathrm{KOH}$ and $\mathrm{NaOH}$ rice straw AC were prepared using a two-step method, and various physical and chemical properties of the AC were determined. The adsorption experiments were also carried out focusing on kinetic and isotherm adsorption processes. In addition, batch studies were carried out to investigate the influence of several parameters like $\mathrm{pH}$, temperature, time, initial dye concentration, and activation agents on the removal of MB from aqueous solutions. The data on adsorption experiments were then interpreted using kinetic and isotherm models to study the behaviour of the adsorption of MB on AC samples.

\section{MATERIALS AND Methods}

\section{MATERIALS}

Rice straw was taken from a paddy field in Sekinchan, Selangor, Malaysia. It was washed with water and dried overnight in an oven at $105^{\circ} \mathrm{C}$. The rice straw was cut into $1-3 \mathrm{~cm}$ pieces using a cutting machine.

\section{RICE STRAW CARBON ACTIVATION}

Rice straw carbon (RSC) was made after the rice straw (RS) was pyrolyzed in a closed chamber at $400{ }^{\circ} \mathrm{C}$ for 4 h. Then, it was sieved to get a size of 60 mesh. The RSC was soaked in the activating agent solution $(\mathrm{NaOH})$ for 24 $h$ at a ratio of 1:4 (RSC:NaOH). Later, it was filtered and oven dried at $105^{\circ} \mathrm{C}$ overnight. The process of activation was carried out in a tube furnace under nitrogen gas flow (100 $\mathrm{mL}$ per $\mathrm{min}$ ) for $2 \mathrm{~h}$ at a temperature of $850{ }^{\circ} \mathrm{C}$. The sample was cooled to room temperature and cleaned with hydrochloric acid $(\mathrm{HCl})$ solution $(1 \mathrm{M})$ and deionized water until a $\mathrm{pH}$ of 6 to 7 in the rinse was reached. The same procedure as above is performed on the $\mathrm{KOH}$ activation agent. The samples were noted as RS (rice straw) or RSC (rice straw carbon). RSACK and RSACNa refer to the RSC activated with $\mathrm{KOH}$ and $\mathrm{NaOH}$, respectively. 


\section{CHARACTERIZATION OF AC}

A Fourier transform infrared spectrometer (FTIR model Bruker, Alpha) was used to analyze the chemical functional groups of the AC samples. The surface analysis of the RSC, RSACK, and RSACNa samples was analyzed using $\mathrm{N}_{2}$ adsorption-desorption analysis (Micromeritics ASAP, 2010) following the nitrogen adsorption and desorption standard at $77 \mathrm{~K}$. The samples were degassed before being analyzed under vacuum for $10 \mathrm{~h}$ at $110^{\circ} \mathrm{C}$. Surface morphology of the RSC, RSACK, and RSACNa were viewed using scanning electron microscopy (SEM) of the FEI model Quanta 400.

\section{ADSORPTION KINETICS EXPERIMENT OF MB ON AC}

An adsorption kinetic study was carried out with different parameters, including initial concentration of MB, temperature, and $\mathrm{pH}$. AC weight of $0.1 \mathrm{~g}$ was added to a flask containing $100 \mathrm{~mL}$ of $\mathrm{MB}$ solution. The $\mathrm{pH}$ of $\mathrm{MB}$ at 3-9 was adjusted using $0.1 \mathrm{M} \mathrm{HCl}$ or $0.1 \mathrm{M} \mathrm{NaOH}$. Experiments at different $\mathrm{MB}$ concentrations (50-300 $\mathrm{mg} / \mathrm{L})$ and temperatures $\left(25-65^{\circ} \mathrm{C}\right)$ were also carried out. The samples in the MB solution were stirred at $250 \mathrm{rpm}$. Aliquots of the solution $(\sim 0.1 \mathrm{~mL})$ were taken at different intervals of time, filtered, and the MB concentration was measured using a UV-Vis Spectrophotometer (UV-vis, Jenway 7315). The value of MB adsorbed at time $t, q_{t}$ $(\mathrm{mg} / \mathrm{g})$, was measured using the following equation:

$$
\mathrm{q}_{\mathrm{t}}=\left(\mathrm{C}_{\mathrm{o}}-\mathrm{C}_{\mathrm{t}}\right) \mathrm{V} / \mathrm{m}
$$

where $\mathrm{C}_{0}$ and $\mathrm{C}_{\mathrm{t}}$ are the early concentration of $\mathrm{MB}(\mathrm{mg} / \mathrm{L})$ and the concentration of $\mathrm{MB}(\mathrm{mg} / \mathrm{L})$ at the interval of time, respectively. $\mathrm{V}$ is the volume of the solution $(\mathrm{mL})$ and $m$ is the amount of adsorbent ( $\mathrm{g})$.

\section{ADSORPTION ISOTHERM EXPERIMENT OF MB ON AC}

Adsorption isotherm studies were conducted by agitating overnight a series of vials containing $0.01 \mathrm{~g}$ of $\mathrm{AC}$ and 10
$\mathrm{mL}$ of $\mathrm{MB}$ solutions with various initial concentrations (100-300 mg/L) in a water bath shaker at $25{ }^{\circ} \mathrm{C}$ with a constant speed of $150 \mathrm{rpm}$. The procedure was repeated at temperatures $45^{\circ} \mathrm{C}$ and $65^{\circ} \mathrm{C}$. The $\mathrm{MB}$ concentration in the supernatant solution $\left(\mathrm{C}_{\mathrm{e}}\right)$ at the equilibrium stage was analyzed using UV-Vis Spectrophotometer. The amount of absorbed MB in the per unit mass of adsorbent $\left(q_{e}\right)$ was measured from the differences in concentration of the $\mathrm{MB}$ at equilibrium and at the beginning $\left(\mathrm{C}_{\mathrm{o}}\right)$; the equation is as follows:

$$
\mathrm{q}_{\mathrm{e}}=\left(\mathrm{C}_{\mathrm{o}}-\mathrm{C}_{\mathrm{e}}\right) \mathrm{V} / \mathrm{m}
$$

where $\mathrm{m}$ is the mass of the $\mathrm{AC}(\mathrm{g})$, and $\mathrm{V}$ is the volume of the MB $(\mathrm{mL})$.

\section{RESULTS AND DISCUSSION \\ CHARACTERIZATION OF AC}

Figure 1 displays the FTIR results of the RSC, RSACK, and RSACNa. The absorbance at $1043 \mathrm{~cm}^{-1}$ is from $\mathrm{O}-\mathrm{H}$ bending (San Miguel et al. 2003). RSC showed weak bands at $2800-2900 \mathrm{~cm}^{-1}$ suggesting stretching vibrations of the $\mathrm{C}-\mathrm{H}$ bonds of the methylene groups $\left(-\mathrm{CH}_{2}-\right)$ (Cazetta et al. 2011). These bands do not exist in the RSACK and RSACNa samples. This may be due to the decomposition of the $\mathrm{C}-\mathrm{H}$ bonds to develop an aromatic $\mathrm{C}=\mathrm{C}$ bond, which is more stable at higher activation temperature (Zhu et al. 2012). The peak at $1380 \mathrm{~cm}^{-1}$ is believed to be due to the deformation of the aliphatic of $\mathrm{CH}_{2}$ or $\mathrm{CH}_{3}$ groups or $\mathrm{O}-\mathrm{H}$ bending of phenolic- $\mathrm{OH}$. It became weaker for the RSACK and RSACNa samples, suggesting aromatization and dehydration presence from the condensation and decomposition of volatile matters ( $\mathrm{Wu}$ et al. 2012). The band at $1737 \mathrm{~cm}^{-1}$, which belongs to $\mathrm{C}=\mathrm{O}$ stretching in aldehyde, appeared on the surface site of RSACK and RSACNa. This could be due to the instability of the thermal aldehyde and ketone group at the high temperature (Hamza et al. 2016). The peak around $1520-1620 \mathrm{~cm}^{-1}$ is related

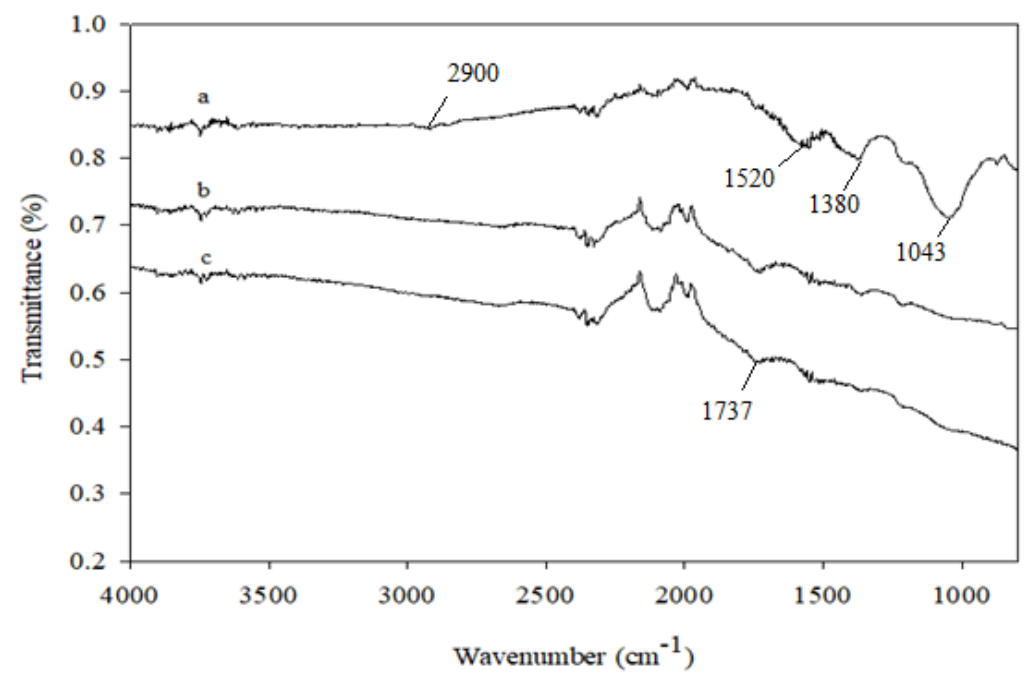

FIGURE 1. FTIR spectrum of (a) RSC, (b) RSACK, and (c) RSACNa 
to the $\mathrm{C}=\mathrm{C}$ stretching in aromatic rings (El-Hendawy 2003). The spectra of RSACK and RSACNa at 3100-3600 $\mathrm{cm}^{-1}$ for $\mathrm{OH}$ stretching absorption decreased as compared to RSC because of the absence of $\mathrm{OH}$ as the result of heating from the carbonization and activation processes. This may result from the development of the aromatic structure $(\mathrm{Oh}$ et al. 2003).

The porosity properties including surface area $\left(\mathrm{S}_{\mathrm{BET}}\right)$, total pore volume $\left(\mathrm{V}_{\text {total }}\right)$, and pore size of RSC, RSACK, and RSACNa obtained from $\mathrm{N}_{2}$ absorption by using the BET model are listed in Table 1. RSACK samples exhibited a higher BET surface area with a value of $2005.9 \mathrm{~m}^{2} / \mathrm{g}$ than $\operatorname{RSACNa}\left(332.8 \mathrm{~m}^{2} / \mathrm{g}\right)$ and $\operatorname{RSC}\left(1.16 \mathrm{~m}^{2} / \mathrm{g}\right) . \mathrm{KOH}$ acts as a better activating agent than $\mathrm{NaOH}$. The $\mathrm{KOH}$ activation results in a larger surface area. This can be attributed to $\mathrm{KOH}$ activation leading to the creation of more micropores resulting in a higher micropore volume and, therefore, producing porous carbon with a higher surface area (LilloRódenas et al. 2001). Improvement of the BET surface area might stem from the release of volatile components during the heat activation treatment process. $\mathrm{KOH}$ as an activating agent reacted with the reactive center of the carbonized material, for example, disorganized carbon, carbon with heteroatoms, and carbon on graphene edges; thus, it created new pores and widened existing ones (Zhang et al. 2008). From Table 1, porous carbon produced by $\mathrm{KOH}$ activation has a smaller pore diameter than those produced by $\mathrm{NaOH}$ activation. $\mathrm{NaOH}$ activation creates porous carbons with a lower micropore volume than in $\mathrm{NaOH}$; these results are consistent with Guo et al. (2003). The increase in microporosity was related to the nature of the alkali cation of the active agent in the following order: $\mathrm{Li}<\mathrm{Na}<\mathrm{K}<\mathrm{Rb}<\mathrm{Cs}$; in this case, $\mathrm{KOH}$ had more alkali cation than $\mathrm{NaOH}$ and, thus, it had a greater tendency to react with the carbon of the precursor to create pores (Guo et al. 2003). The possible chemical reactions between alkali hydroxide and carbon occurring during the activation process can be (Chunlan et al. 2005):

$$
\begin{gathered}
4 \mathrm{KOH}+\mathrm{C} \rightarrow \mathrm{K}_{2} \mathrm{CO}_{3}+\mathrm{K}_{2} \mathrm{O}+2 \mathrm{H}_{2} \\
2 \mathrm{~K}_{2} \mathrm{O}+\mathrm{C} \rightarrow 4 \mathrm{~K}+\mathrm{CO}_{2} \\
\mathrm{~K}_{2} \mathrm{CO}_{3}+2 \mathrm{C} \rightarrow 2 \mathrm{~K}+3 \mathrm{CO}
\end{gathered}
$$

The process of activation produces hydrogen gas, carbonate, and potassium compound $\left(\mathrm{K}\right.$ or $\left.\mathrm{K}_{2} \mathrm{O}\right)$. The metallic potassium is removed during the washing process, potassium carbonate is decomposed during activation, and the $\mathrm{CO}_{2}$ gas is released. The activating agent reaction with the carbon precursor formed the decomposition of the volatile organic compounds and created the porous surface of the AC samples. The gasification process during activation using suitable activating agents is very important for pore development (Muniandy et al. 2014).

TABLE 1. Results of surface analysis of RSC, RSACK, and RSACNa

\begin{tabular}{lccc}
\hline & RSC & RSACK & RSACNa \\
\hline $\mathrm{S}_{\mathrm{BET}}\left(\mathrm{m}^{2} / \mathrm{g}\right)$ & 1.16 & 2005.90 & 332.81 \\
$\mathrm{~V}_{\text {micro }}\left(\mathrm{cm}^{3} / \mathrm{g}\right)$ & 0.00165 & 0.778 & 0.130 \\
$\mathrm{~V}_{\text {total }}\left(\mathrm{cm}^{3} / \mathrm{g}\right)$ & 0.0028 & 1.07 & 0.235 \\
Average pore size $(\mathrm{nm})$ & 9.72 & 2.13 & 2.82 \\
\hline
\end{tabular}

The SEM results of RSC, RSACK, and RSACNa are demonstrated in Figure 2(a), 2(b), and 2(c), respectively. No pores are found on the RSC surfaces, but pores are seen on the surface of RSACK and RSACNa samples after the chemical activation process. RSACK samples from $\mathrm{KOH}$ activation developed more pores than RSACNa, as shown in Figure 2(b) and 2(c). The high number of pores resulted in the high BET surface area of RSACK, as reported in Table 1. These results are similar to results from previous studies (Oh \& Park 2002; Zhang et al. 2009) where the KOH activation created more pores and produced high BET values. 

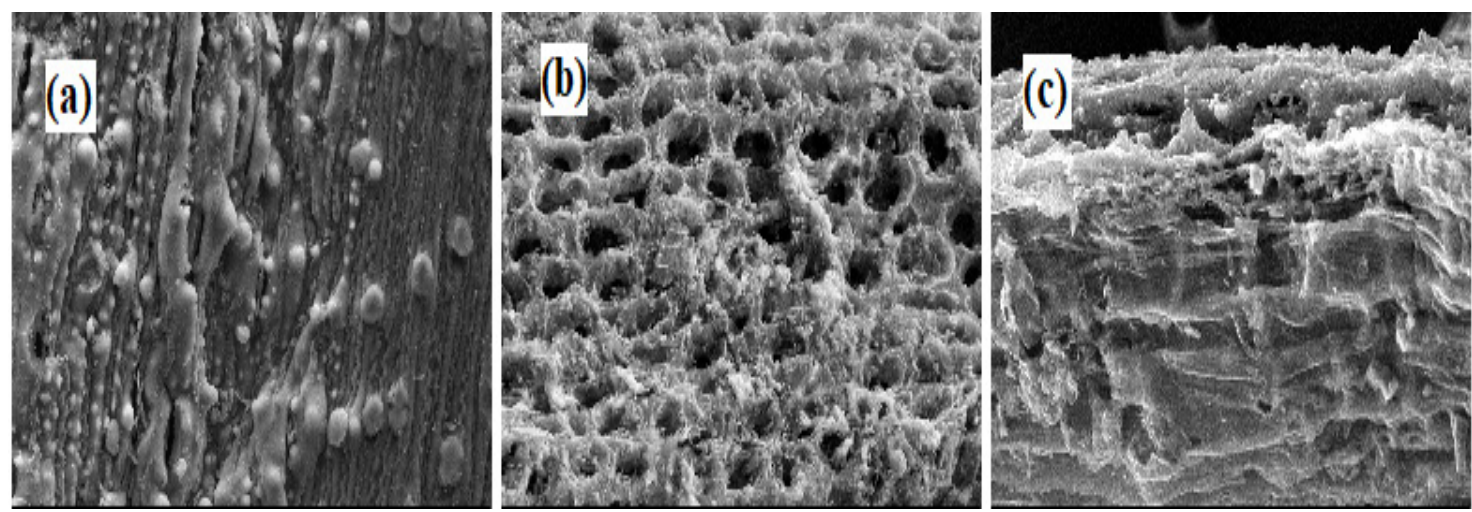

FIGURE 2. SEM of (a) RSC, (b) RSACK, and (c) RSACNa samples

\section{ADSORPTION KINETICS EXPERIMENT EFFECT OF INITIAL $\mathrm{pH}$}

Figure 3 shows the adsorption kinetics of RSACK and RSACNa on the MB at various pHs. The experiments were done at $25{ }^{\circ} \mathrm{C}$. The adsorption capacity of both the RSACK and RSACNa increased from 91.5 to $98.7 \mathrm{mg} / \mathrm{g}$ and 59.5 to $90.3 \mathrm{mg} / \mathrm{g}$, respectively, when the $\mathrm{pH}$ of the solution increased from 3 to 7 . This was due to the increase in surface charge of the adsorbent whenever the $\mathrm{pH}$ increased (Sajab et al. 2013). The increase can be due to lower competition among the molecules of MB and
$\mathrm{H}+$ ions during the formation of electrostatic attraction with the functional groups on the adsorbent's surface. The adsorption decreased at $\mathrm{pH} 9$ in both samples. A similar result was reported for studies of $\mathrm{MB}$ adsorption with lignocellulosic adsorbents (Batzias \& Sidiras 2007; Hamdaoui 2006; Sajab et al. 2011). They found that adsorption became higher as $\mathrm{pH}$ values of adsorbate solution increased until $\mathrm{pH} 7$ and a tendency to decrease at $\mathrm{pH}$ 9. It could be due to the less competition between ion of $\mathrm{MB}$ and $\mathrm{H}+$ which makes ionic $\mathrm{MB}$ more attached to the adsorbent surfaces.

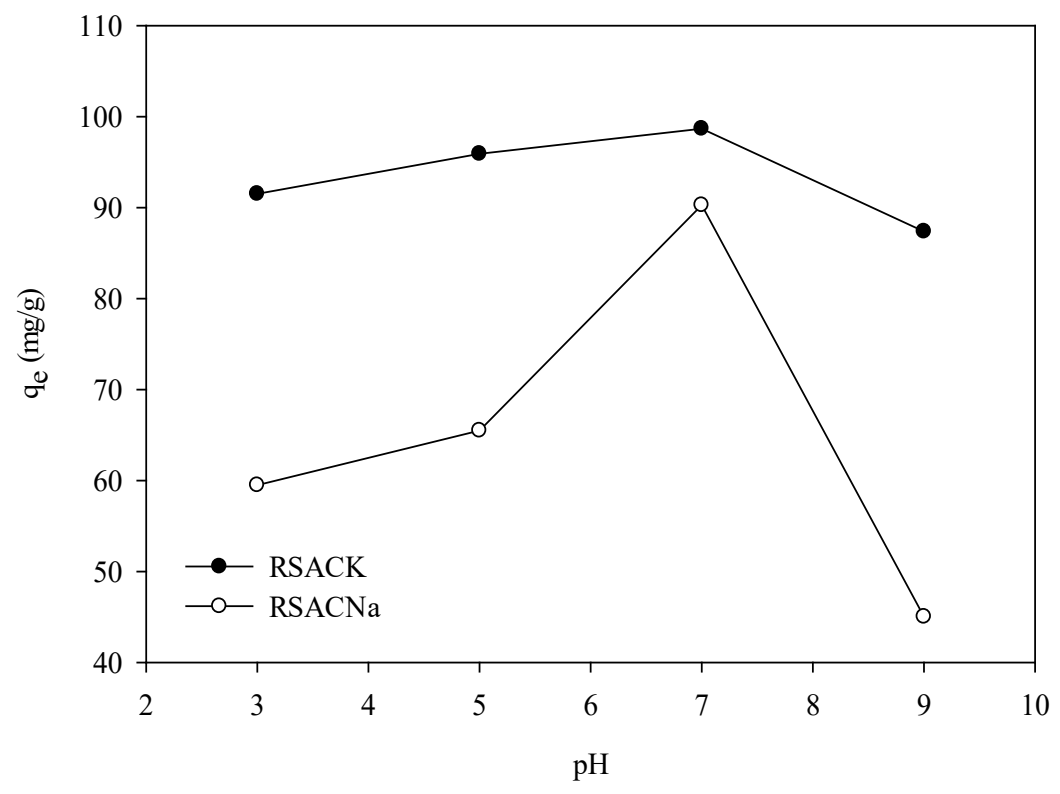

FIGURE 3. Influence of $\mathrm{pH}$ on adsorption kinetics of MB on RSACK and RSACNa $\left(\mathrm{C}_{0}: 100 \mathrm{mg} / \mathrm{L}\right.$; temperature: $\left.25^{\circ} \mathrm{C}\right)$ 


\section{EFFECT OF MB CONCENTRATION}

The study on adsorption was performed with various MB concentrations (i.e. 50 to $300 \mathrm{mg} / \mathrm{L}$ ) and the results are shown in Figure 4. The increasing concentration of MB has increased the adsorption kinetic of the samples and required a longer time to reach the equilibrium of adsorption. The strong competition at high initial $\mathrm{MB}$ concentrations between MB molecules in aqueous conditions results in these molecules being concentrated on the adsorbents with a developed pore system (Lin et al. 2013). RSACK samples were adsorbed at higher MB and reached adsorption equilibrium faster than RSACNa. The factor of surface area or pore higher in RSACK samples may have caused more MB to be adsorbed onto adsorbent pore surfaces. The large specific area of adsorbents resulted in more $\mathrm{MB}$ adsorbed which does not require diffusion into the inner porous structure of the adsorbent (Chia et al. 2013).
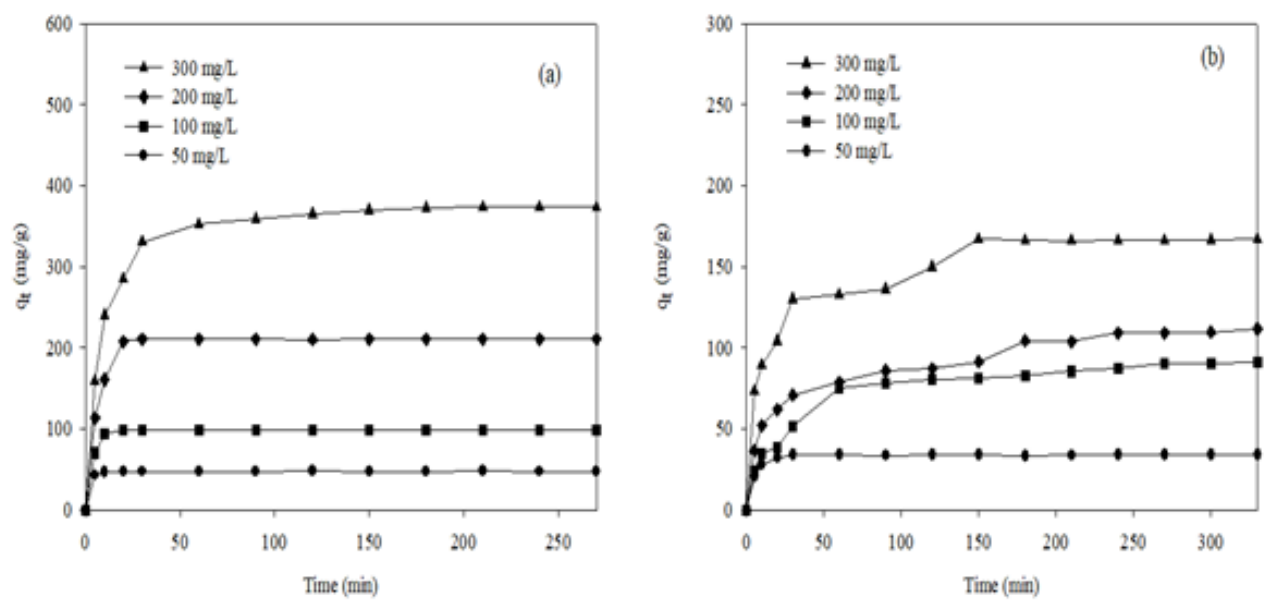

FIGURE 4. Influence of initial concentration of MB on adsorption kinetics of (a) RSACK and (b) RSACNa samples (pH: 7; temperature: $25^{\circ} \mathrm{C}$ )

\section{EFFECT OF TEMPERATURE}

In order to study the effect of temperature on the MB adsorption by the adsorbents, the experiments were carried out at regular time intervals from 5 min up to equilibrium under the temperatures of 25,45 and $65^{\circ} \mathrm{C}$, and the $\mathrm{pH}$ value of the solution with MB concentration at $100 \mathrm{mg} / \mathrm{L}$ was adjusted to 7 . Figure 5 displays the relationship between the temperature and the amount of MB adsorbed by the RSACK and RSACNa, respectively. One can see from Figure 5 that the amount of MB removed by the carbon increased whenever temperatures went up from 25 to 45 , and $65^{\circ} \mathrm{C}$. The change in $\mathrm{MB}$ removal in the experiments was affected significantly by temperature. It could be due to the mobility of the dye molecules and the number of active sites were increased for the activities of adsorption at elevated temperature (Senthilkumaar et al. 2006).

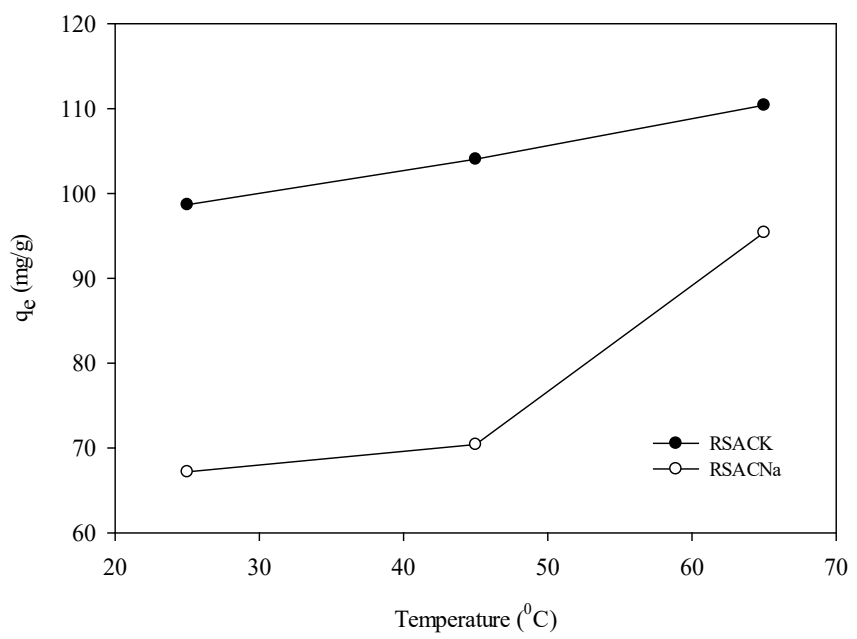

FIGURE 5. Influence of temperature on adsorption kinetics of MB on RSACK and RSACNa $\left(\mathrm{C}_{0}: 100 \mathrm{mg} / \mathrm{L} ; \mathrm{pH}: 7\right)$ 


\section{PSEUDO-FIRST AND PSEUDO-SECOND ORDER MODEL}

The kinetic models used to study and describe the adsorption of MB are pseudo-first-order or pseudosecond-order models. The equation of the pseudo-firstorder model is as follows (Lagergren 1898):

$$
\ln \left(q_{e}-q_{t}\right)=\ln q_{e}-k_{l} t,
$$

where $q_{e}$ and $q_{t}$ are the amounts of adsorbed MB on the adsorbent $(\mathrm{mg} / \mathrm{g})$ at equilibrium and at time $t$, respectively. $k_{1}$ is the pseudo-first-order rate constant $\left(\mathrm{min}^{-1}\right)$. This model suggests that the adsorption rate of adsorbate with time is proportional to the difference in adsorption capacity at equilibrium and the adsorbed amount. The equation of the pseudo-second-order is as follows (Ho \& Mckay 1999):

$$
\frac{t}{q_{\mathrm{t}}}=\frac{1}{k_{2} q_{\mathrm{e}}^{2}}+\frac{1}{q_{\mathrm{e}}} t
$$

where $k_{2}$ is the rate constant of the pseudo-second-order. This model suggests that the rate-limiting step involves chemisorption of adsorbate on the adsorbent.

Table 2 shows the kinetic data calculated from pseudo-first- and second-order models using the experimental data. It was found that pseudo-second-order model has higher correlation coefficients and fits the experimental data better compared to pseudo-first-order. The applicability of the pseudo-second-order model shows that limiting the step rate is chemisorption involving forces caused by the exchange of electrons among adsorbent and adsorbate (Raoul et al. 2014).

TABLE 2. Kinetic data calculated from pseudo-first- and second-order models for the adsorption of MB

\begin{tabular}{lcccccccc}
\hline & \multicolumn{3}{c}{ Pseudo-first-order } & \multicolumn{3}{c}{ Pseudo-second-order } \\
& $C_{0}$ & $q_{\mathrm{e}} \exp$ & $q_{\mathrm{e}}$ cal & $k_{1}$ & $r^{2}$ & $q_{\mathrm{e}} \mathrm{cal}$ & $k_{2}$ & $r^{2}$ \\
\hline \multirow{2}{*}{ RSACK } & 50 & 47.28 & 2.99 & 0.127 & 0.682 & 47.39 & 0.371 & 0.999 \\
& 100 & 98.82 & 43.17 & 0.213 & 0.825 & 99.01 & 0.0173 & 1 \\
& 200 & 210.75 & 690.21 & 0.295 & 0.975 & 212.77 & 0.00283 & 0.999 \\
& 300 & 373.61 & 163.12 & 0.0279 & 0.961 & 384.62 & 0.000436 & 0.999 \\
& 50 & 33.79 & 43.74 & 0.193 & 0.954 & 34.01 & 0.0199 & 0.999 \\
& 100 & 90.28 & 35.18 & 0.0098 & 0.911 & 92.59 & 0.000820 & 0.998 \\
& 200 & 109.27 & 62.16 & 0.0175 & 0.918 & 116.28 & 0.000558 & 0.998 \\
& 300 & 166.95 & 79.41 & 0.0125 & 0.835 & 169.49 & 0.000513 & 0.996 \\
\hline
\end{tabular}

\section{INTRAPARTICLE DIFFUSION MODEL}

The intraparticle diffusion model (Weber 1963) was used to investigate the diffusion mechanism of the adsorbateadsorbent:

$$
q_{\mathrm{ref}}=k_{\mathrm{i}} t_{\mathrm{ref}}^{1 / 2}+C
$$

where $k_{i}$ is the intraparticle diffusion constant which shows the presence of the intra-particle diffusion process calculated from the slope of a plot of $\mathrm{q}_{\mathrm{t}} \mathrm{vs}^{0.5}$ and $C$ is the intercept (mg/g) (Weber 1963); the value of C reflects the boundary layer thickness. The larger the intercept, the greater the boundary layer effect (Chandrasekhar \& Pramada 2006).

The results of intraparticle diffusion data analyses are presented in Table 3 and Figure 6. Two predictions can be made from the plot. Intraparticle diffusion is the rate-controlling step if the straight-line plot passes through the origin. However, if not, the process of adsorption may involve other mechanisms along with the intraparticle diffusion (Rubín et al. 2010). Figure 6 shows that the plots for (a) RSACK and (b) RSACNa do not go through the origin, but a three linear adsorption process was 
found. The first linear process was likely the external surface or boundary layer adsorption; the second was the adsorption where the intraparticle diffusion was rate controlled. The third was the equilibrium step where the intraparticle diffusion started to slow down because of the low adsorbate concentrations in the solution (Boyd et al. 1947; Kumar \& Gaur 2011). The influence of mass transfer caused the shape of the $\mathrm{q}_{\mathrm{t}}$ versus $t^{0.5}$ plot to be curved at a small-time limit (Annadurai et al. 2002). This also proved that adsorption of the MB onto the adsorbent is a multi-step process, including adsorption on the external surface and diffusion into the interior. The values of $k i$ and $C$ are much higher with increasing initial MB concentration, resulting in more intraparticle diffusion and boundary layer effect or surface active sites, respectively (Chandrasekhar \& Pramada 2006). In addition, the $k i$ and $C$ values of RSACK are higher than for RSACNa, which suggests that the RSACK has more intraparticle diffusion and surface-active sites.
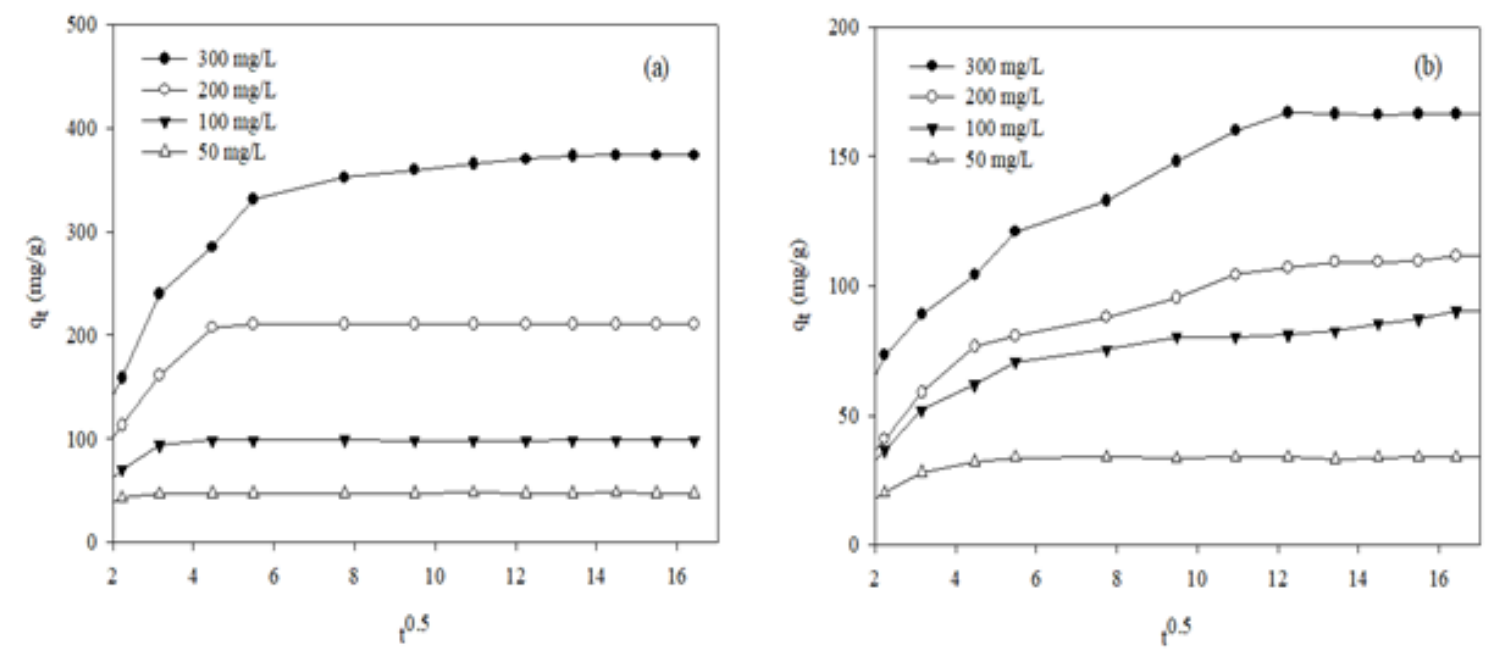

FIGURE 6. Adsorption kinetics of MB on (a) RSACK and (b) RSACNa samples: Intraparticle diffusion

TABLE 3. Kinetic data calculated from intraparticle diffusion model for the adsorption of MB

\begin{tabular}{ccccc}
\hline & $\begin{array}{c}C_{0} \\
(\mathrm{mg} / \mathrm{L})\end{array}$ & $\begin{array}{c}k_{\mathrm{i}} \\
\left(\mathrm{mg} / \mathrm{g} \mathrm{h}^{1 / 2}\right)\end{array}$ & $\begin{array}{c}C \\
(\mathrm{mg} / \mathrm{g})\end{array}$ & $r^{2}$ \\
\hline RSACK & 50 & 1.814 & 39.68 & 0.699 \\
& 100 & 12.1 & 47.85 & 0.8 \\
& 200 & 30.71 & 55.21 & 0.903 \\
& 300 & 50.3 & 60.51 & 0.96 \\
RSACNa & 50 & 4.02 & 13.07 & 0.901 \\
& 100 & 11.06 & 13.8 & 0.948 \\
& 200 & 18.68 & 7.04 & 0.999 \\
& 300 & 14.25 & 42.19 & 0.994 \\
\hline
\end{tabular}




\section{ADSORPTION ISOTHERM EXPERIMENT LANGMUIR AND FREUNDLICH ISOTHERM MODEL}

The adsorption isotherm is important for describing the mechanism of adsorption of the cationic MB interaction on the adsorbent surfaces. Langmuir and Freundlich models are applied to study the suitable adsorption isotherms. The Langmuir isotherm model assumes that the adsorbent surface is homogeneously covered by monolayer adsorbate; each molecule that adsorbed onto the adsorbent surface contained the same adsorption activation energy (Chia et al. 2013). The Langmuir isotherm concerns the principle where the adsorbent occupies the adsorption sites at the interface of the solid. This is related to the maximum adsorption capacity (Chandrasekhar \& Pramada 2006). The adsorption Langmuir isotherm is expressed as:

$$
\frac{C_{e}}{q_{e}}=\frac{1}{Q_{0} b}+\frac{C_{e}}{Q_{0}}
$$

where $Q_{0}$ is the maximum adsorption capacity per unit mass of adsorbents $(\mathrm{mg} / \mathrm{g})$; and $b$ is a constant of the adsorption energy $(1 / \mathrm{mg})$. To determine whether adsorption is 'favorable' or 'unfavorable', an equilibrium parameter, $R_{\mathrm{L}}$, was calculated using the equation:

$$
R_{L}=\frac{1}{1+b C_{m}}
$$

where $b$ is the Langmuir constant $(\mathrm{L} / \mathrm{mg})$; and $C_{\mathrm{m}}$ is the highest initial MB concentration $(\mathrm{mg} / \mathrm{L})$. The value of $R_{\mathrm{L}}$ indicates the type of isotherm to be favorable $\left(0<R_{\mathrm{L}}<1\right)$, unfavorable $\left(R_{\mathrm{L}}>1\right)$, irreversible $\left(R_{\mathrm{L}}=0\right)$, or linear $\left(R_{\mathrm{L}}=\right.$ 1) (Sajab et al. 2013).

The Freundlich isotherm model explains adsorption onto heterogeneous surfaces. The mechanism of adsorption may not relate to the Langmuir model assumption but may be related to the Freundlich model (Chiou 2002). The Freundlich isotherm is expressed as:

$$
\ln q_{e}=\ln K_{F}+\frac{1}{n} \ln C_{e}
$$

where $K_{F}$ and $1 / \mathrm{n}$ are the Freundlich constants, $K_{F}$ is the relative adsorption capacity of the adsorbents, and $\mathrm{n}$ is the degree of dependence of adsorption on the equilibrium MB concentration.

TABLE 4. Isotherm data calculated from Langmuir and Freundlich for adsorption MB

\begin{tabular}{lcccccccc}
\hline & $\begin{array}{r}\text { Temperature } \\
\left({ }^{\circ} \mathrm{C}\right)\end{array}$ & $Q_{0}$ & $b$ & $R_{\mathrm{L}}$ & $r^{2}$ & $K_{\mathrm{F}}$ & $n_{\mathrm{F}}$ & $r^{2}$ \\
\hline RSACK & 25 & 357.1 & 1.4 & 0.00238 & 0.993 & 508.16 & 1.75 & 0.953 \\
& 45 & 400 & 2.27 & 0.00147 & 0.998 & 292.8 & 1.85 & 0.965 \\
& 65 & 588.2 & 1.88 & 0.00176 & 0.998 & 633.65 & 1.36 & 0.992 \\
RSACNa & 25 & 131.6 & 0.374 & 0.0088 & 0.999 & 75.20 & 8.50 & 0.724 \\
& 45 & 144.9 & 1.64 & 0.00203 & 0.994 & 78.05 & 5.13 & 0.735 \\
& 65 & 232.6 & 0.86 & 0.00386 & 0.999 & 95.04 & 4.19 & 0.575 \\
\hline
\end{tabular}

TABLE 5. Comparison on adsorption performance of AC samples produced from various lignocellulosic biomass

\begin{tabular}{lcc}
\hline \multicolumn{1}{c}{ Adsorbent } & Maximum adsorption, $Q_{0}(\mathrm{mg} / \mathrm{g})$ & Reference \\
\hline AC from bamboo & 143.2 & (Kannan \& Sundaram 2001) \\
AC from empty fruit bunch & 344.8 & (Foo \& Hameed 2011) \\
AC from coconut husk & 434.8 & (Tan et al. 2008) \\
AC from peanut shell & 225.8 & (Wu, Guo \& Fu 2013) \\
AC from rattan sawdust & 294.1 & (Hameed et al. 2007a) \\
AC from bamboo & 454.2 & (Hameed et al. 2007b) \\
AC from banana trunk & 59.5 & (Danish et al. 2018) \\
AC from durian shell & 289.3 & (Hameed \& Hakimi 2008) \\
AC from rice husk & 343.5 & (Kannan \& Sundaram 2001) \\
RSACK & 588.2 & This study \\
RSACNa & 232.6 & This study \\
\hline
\end{tabular}


Both Freundlich and Langmuir constants were calculated from the slopes and intercepts of the plots of $\ln q_{e}$ versus $\ln C_{e}$ and $C_{e} / q_{e}$ versus $C_{e}$ (Figure 7 ), and the results are tabulated in Table 4 . The adsorption values of MB on the RSACK and RSACNa have followed the Langmuir isotherm model due to higher correlation coefficients $\left(r^{2}\right)$ as compared to the Freundlich isotherm model. The results indicate that the monolayer adsorption process of MB onto the RSACK and RSACNa has occurred. Furthermore, adsorption is favorable at high temperatures as the results of the value of $Q_{0}$ and $K_{F}$ increased with the rise in temperature. The increase in adsorption capacity related to the temperature showed that the active surfaces available for adsorption increase with increased temperature (El-Kamash et al. 2005). A similar pattern has also been reported from a study on removing MB using rice husk activated carbon (Lin et al. 2013). Data on adsorption capacity, $\left(Q_{0}\right)$, show that RSACK is more favorable for adsorption of MB ions than RSACNa. RSACK had a higher surface area and pore volume than RSACNa, which can be attributed to the high adsorption capacity, $\left(Q_{0}\right)$. Chandrasekhar and Pramada (2006) also found a similar trend in removing $\mathrm{MB}$ using rice ash. The $R_{L}$ data from the adsorption at different temperatures are less than 1 and higher than 0 , suggesting the favorable adsorption of MB on RSACK and RSACNa. Table 5 displays the maximum adsorption capacity $\left(\mathrm{Q}_{0}\right)$ of the RSACK and RSACNa and other lignocellulosic AC. The adsorption capacity of RSACK and RSACNa against MB was comparable with other lignocellulosic AC but even higher, especially from RSACK.
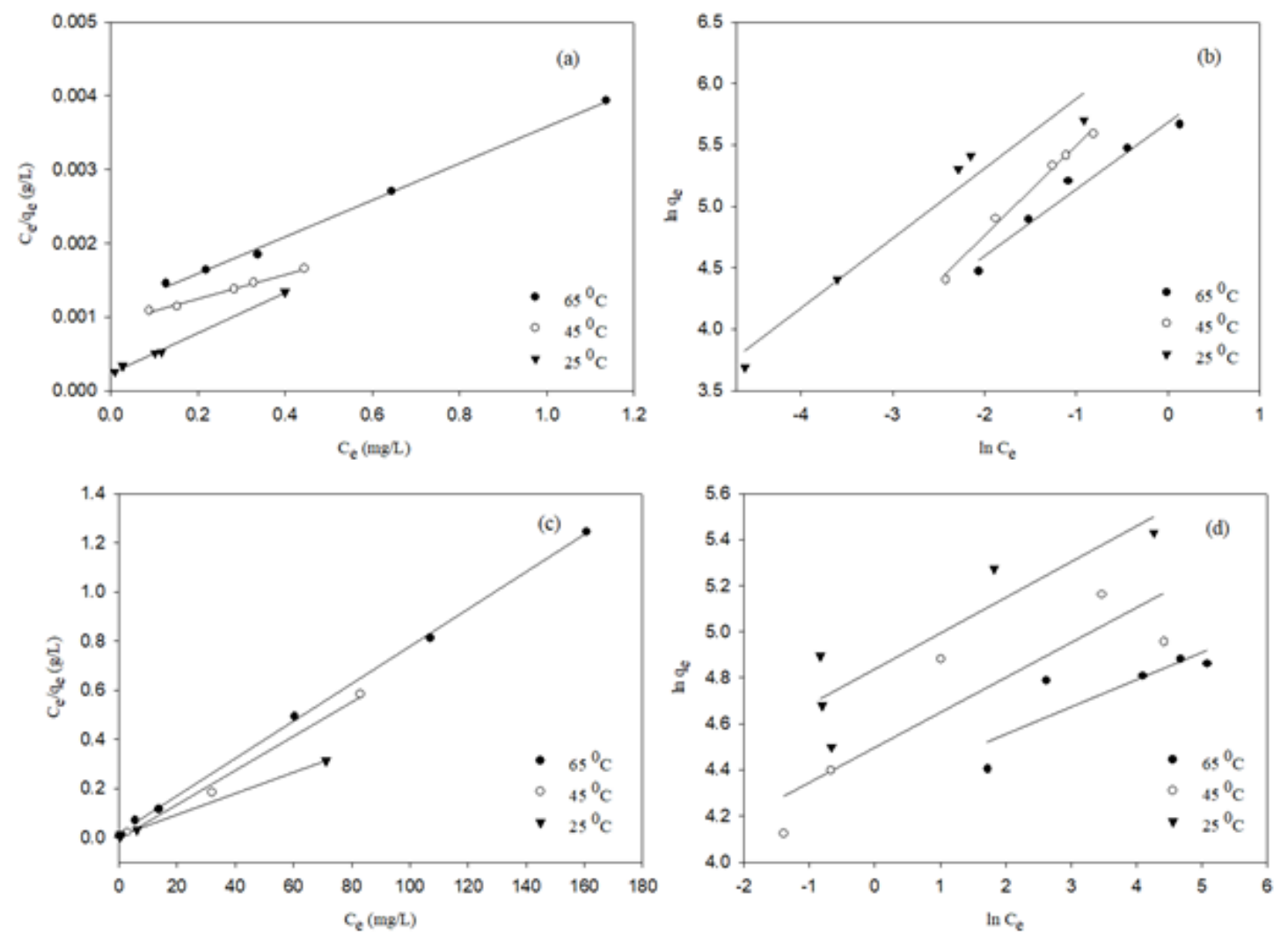

FIGURE 7. Linearized isotherm plots for the adsorption of MB on the RSACK and RSACNa: (a) Langmuir of RSACK, (b) Freundlich of RSACK, (c) Langmuir of RSACNa, (d) Freundlich of RSACNa

\section{THERMODYNAMIC PARAMETERS}

To study the thermodynamic nature of the adsorption process of MB onto adsorbents, parameters of the thermodynamics in the system were calculated and shown in Table 6. The Gibbs free energy change, $\Delta G^{0}$, was the spontaneous fundamental criterion. The negative values mean that at a certain given temperature a reaction occurs spontaneously (Sharaf \& Hassan 2014). The formula is as follows:

$$
\Delta \mathrm{G}^{0}=-\mathrm{RT} \ln \mathrm{K}_{\mathrm{c}}
$$


where $\mathrm{K}_{\mathrm{c}}$ (value of $\mathrm{q}_{\mathrm{e}} / \mathrm{c}_{\mathrm{e}}$ of isotherm) is the sorption equilibrium constant. $\mathrm{R}$ is the universal gas constant (1.987 or $8.314 \mathrm{~J} / \mathrm{mol} \mathrm{K}$ ) and $\mathrm{T}$ is the absolute temperature $(\mathrm{K})$.

TABLE 6. Thermodynamic parameters for the adsorption of MB on RSACK and RSACNa

\begin{tabular}{lccccc}
\hline \multicolumn{1}{c}{ MB concentration $(\mathrm{mg} / \mathrm{L})$} & $\Delta H^{\circ}(\mathrm{kJ} / \mathrm{mol})$ & \multicolumn{2}{c}{$\Delta S^{\circ}$} & \multicolumn{2}{c}{$\Delta G^{\circ}(\mathrm{kJ} / \mathrm{mol})$} \\
\hline RSACK & & $(\mathrm{J} / \mathrm{mol} \mathrm{K})$ & $335 \mathrm{~K}$ & $314 \mathrm{~K}$ & $296 \mathrm{~K}$ \\
100 & 36.88 & 176.17 & -20.56 & -18.05 & -18.37 \\
150 & 33.42 & 164.02 & -19.85 & -17.93 & -18.03 \\
200 & 27.19 & 142.39 & -18.82 & -17.43 & -17.70 \\
250 & 34.80 & 165.05 & -18.74 & -17.27 & -16.62 \\
300 & 23.31 & 124.87 & -16.40 & -16.94 & -15.57 \\
RSACNa & & & & -6.65 \\
100 & 39.98 & 159.98 & -12.60 & -13.54 & -5.36 \\
150 & 63.20 & 233.13 & -14.22 & -13.40 & -1.76 \\
200 & 107.55 & 367.35 & -16.11 & -10.23 & -0.52 \\
250 & 68.80 & 231.55 & -9.70 & -4.48 & -0.54 \\
300 & 29.50 & 97.03 & -3.27 & -1.42 & \\
\hline
\end{tabular}

The negative values of $\Delta G^{0}$ in RSACK and RSACNa (Table 6) indicate that the adsorption process of MB onto RSACK and RSACNa was spontaneous. The free energy change $\Delta \mathrm{G}^{0}$ values increased as the temperature increased, hence implying the strengthening of adsorbateabsorbent interactions at a higher temperature (Daifullah et al. 2007; Sharaf \& Hassan 2014).

The other parameters of thermodynamics, including enthalpy change $\Delta \mathrm{H}^{0}$ and entropy change $\Delta \mathrm{S}^{0}$ of the MB adsorption values, were calculated from the slope and intercept of the graph of the $\ln \mathrm{K}_{\mathrm{c}}$ versus $1 / \mathrm{T}$ by using the van't Hoff equation, as shown herewith.

$$
\ln K_{C}=\frac{\Delta S^{0}}{R}-\frac{\Delta H^{0}}{R T}
$$

The enthalpy changes in $\Delta \mathrm{H}^{0}$ of RSACK and RSACNa was positive, which means the $\mathrm{MB}$ adsorption process is endothermic in nature. Entropy change in $\Delta \mathrm{S}^{0}$ values was positive, indicating the randomness increased adsorbate-adsorbent interface during the process of adsorption (Sajab et al. 2013). All the data of the $\Delta \mathrm{H}^{0}$ and $\Delta \mathrm{S}^{0}$ of RSACK and RSACNa were tabulated in Table 6.

\section{CONCLUSION}

$\mathrm{KOH}$ and $\mathrm{NaOH}$ rice straw $\mathrm{AC}$ were produced via the two-step method. The MB adsorption studies demonstrated that the produced RSACK displays maximum adsorption capacity $\left(Q_{0}\right)$ at $588.24 \mathrm{mg} / \mathrm{g}$, which is higher than RSACNa $(232.56 \mathrm{mg} / \mathrm{g})$. The isotherm adsorption data followed the Langmuir model, suggesting the monolayer adsorption of MB onto the adsorbents. The intraparticle diffusion model suggested that the adsorption process of RSACK and RSACNa toward MB occurred via the external mass transfer and diffusion of MB molecules to the surface of adsorbents.

\section{ACKNOWLEDGMENTS}

The authors acknowledge MARDI, Universiti Kebangsaan Malaysia and the Ministry of Education for the financial support via the research project grants DIP-2019-003.

\section{REFERENCES}

Abechi, S.E., Gimba, C.E., Uzairu, A., Kagbu, J.A. \& Ocholi, O.J. 2013. Equilibrium adsorption studies of methylene blue onto palm kernel shell-based activated carbon. International Refereed Journal of Engineering and Science (IRJES) 2(5): $38-45$. 
Annadurai, G., Juang, R.S. \& Lee, D.J. 2002. Use of cellulosebased wastes for adsorption of dyes from aqueous solutions. Journal of Hazardous Materials 92(3): 263-274.

Aznie, R.C. \& Mohd Zainol, R. 2014. Farmers knowledge on potential uses of rice straw: An assessment in Mada and Sekinchan, Malaysia. Geografia - Malaysian Journal of Society and Space 10(5): 30-43.

Banat, I., Singh-Nee, N.P., Singh, D. \& Marchant, R. 1996. Microbial decolorization of textile-dye-containing effluents: A review. Bioresource Technology 58(3): 217-227.

Bansal, R.C. \& Goyal, M. 2005. Activated Carbon Adsorption. Boca Raton: Taylor \& Francis.

Batzias, F.A. \& Sidiras, D.K. 2007. Simulation of dye adsorption by beech sawdust as affected by $\mathrm{pH}$. Journal of Hazardous Materials 141(3): 668-679.

Bhattacharya, K.G. \& Sharma, A. 2005. Kinetics and thermodynamics of methylene blue adsorption on neem (Azadirachta indica) leaf powder. Dyes and Pigments 65(1): 51-59.

Boyd, G.E., Adamson, A.W. \& Myers, L.S. 1947. The exchange adsorption of ions from aqueous solutions by organic zeolites. II. kinetics. Journal of the American Chemical Society 69(11): 2836-2848.

Cazetta, A.L., Vargas, A.M.M., Nogami, E.M., Kunita, M.H., Guilherme, M.R., Martins, A.C., Silva, T.L., Moraes, J.C.G. \& Almeida, V.C. 2011. NaOH-activated carbon of high surface area produced from coconut shell: kinetics and equilibrium studies from the methylene blue adsorption. Chemical Engineering Journal 174(1): 117-125.

Chandrasekhar, S. \& Pramada, P.N. 2006. Rice husk ash as an adsorbent for methylene blue-effect of ashing temperature. Adsorption 12(1): 27-43.

Chia, C.H., Razali, N.F., Sajab, M.S., Zakaria, S., Huang, N.M. \& Lim, H.N. 2013. Methylene blue adsorption on graphene oxide. Sains Malaysiana 42(6): 819-826.

Chiou, C.T. 2002. Partition and Adsorption of Organic Contaminants in Environmental Systems. New York: Wiley/ Interscience.

Chunlan, L., Shaoping, X., Yixiong, G., Shuqin, L. \& Changhou, L. 2005. Effect of pre-carbonization of petroleum cokes on chemical activation process with KOH. Carbon 43(11): 2295-2301.

Crini, G. 2006. Non-conventional low-cost adsorbents for dye removal: A review. Bioresource Technology 97: 1061-1085.

Daifullah, A.A.M., Yakout, S.M. \& Elreefy, S.A. 2007. Adsorption of fluoride in aqueous solutions using $\mathrm{KMnO}_{4}$-modified activated carbon derived from steam pyrolysis of rice straw. Journal of Hazardous Materials 147(1-2): 633-643.

Danish, M., Ahmad, T., Nadhari, W.N.A.W., Ahmad, M., Khanday, W.A., Ziyang, L. \& Pin, Z. 2018. Optimization of banana trunk-activated carbon production for methylene blue-contaminated water treatment. Applied Water Science 8(1): 1-11.

Danish, M., Hashim, R., Ibrahim, M.N.M. \& Sulaiman, O. 2014. Optimized preparation for large surface area activated carbon from date (Phoenix dactylifera L.) stone biomass. Biomass and Bioenergy 61: 167-178.

El-Hendawy, A.N.A. 2003. Influence of $\mathrm{HNO}_{3}$ oxidation on the structure and adsorptive properties of corncob-based activated carbon. Carbon 41(4): 713-722.
El-Kamash, A.M., Zaki, A.A. \& El Geleel, M.A. 2005. Modeling batch kinetics and thermodynamics of zinc and cadmium ions removal from waste solutions using synthetic zeolite A. Journal of Hazardous Materials 127(1-3): 211-220.

El-Maghraby, A. \& Deeb, H.A.E. 2018. Removal of a basic dye from aqueous solution by adsorption using rice hulls. Global NEST Journal Global NEST: The International Journal 13(1): 90-98.

Elimelech, M. 2006. The global challenge for adequate and safe water. Journal of Water Supply: Research and Technology - Aqua 55(1): 3-10.

Foo, K.Y. \& Hameed, B.H. 2011. Preparation of oil palm (Elaeis) empty fruit bunch activated carbon by microwave-assisted $\mathrm{KOH}$ activation for the adsorption of methylene blue. Desalination 275(1-3): 302-305.

Gao, P., Liu, Z., Xue, G., Han, B. \& Zhou, M. 2011. Preparation and characterization of activated carbon produced from rice straw by $\left(\mathrm{NH}_{4}\right)_{2} \mathrm{HPO}_{4}$ activation. Bioresource Technology 102(3): 3645-3648.

Ghosh, D. \& Bhattacharyya, K.G. 2002. Adsorption of methylene blue on kaolinite. Applied Clay Science 20(6): 295-300.

Guo, J.Z., Li, B., Liu, L. \& Lv, K. 2014. Removal of methylene blue from aqueous solutions by chemically modified bamboo. Chemosphere 111: 225-231.

Guo, Y., Yu, K., Wang, Z. \& Xu, H. 2003. Effects of activation conditions on preparation of porous carbon from rice husk. Carbon 41(8): 1645-1648.

Hamdaoui, O. 2006. Batch study of liquid-phase adsorption of methylene blue using cedar sawdust and crushed brick. Journal of Hazardous Materials 135(1-3): 264-273.

Hameed, B.H. \& Hakimi, H. 2008. Utilization of durian (Durio zibethinus Murray) peel as low cost sorbent for the removal of acid dye from aqueous solutions. Biochemical Engineering Journal 39(2): 338-343.

Hameed, B.H., Ahmad, A.L. \& Latiff, K.N.A. 2007a. Adsorption of basic dye (methylene blue) onto activated carbon prepared from rattan sawdust. Dyes and Pigments 75(1): 143-149.

Hameed, B.H., Din, A.T.M. \& Ahmad, A.L. 2007b. Adsorption of methylene blue onto bamboo-based activated carbon: Kinetics and equilibrium studies. Journal of Hazardous Materials 141(3): 819-825.

Hamza, U.D., Nasri, N.S., Amin, N.A.S., Mohammed, J. \& Zain, H.M. 2016. Characteristics of oil palm shell biochar and activated carbon prepared at different carbonization times. Desalination and Water Treatment 57(17): 7999-8006.

Hirunpraditkoon, S., Tunthong, N., Ruangchai, A. \& Nuithitikul, K. 2011. Adsorption capacities of activated carbons prepared from bamboo by $\mathrm{KOH}$ activation. World Academy of Science, Engineering and Technology 78: 711-715.

Ho, Y.S. \& Mckay, G. 2003. Sorption of dyes and copper ions onto biosorbents. Process Biochemistry 38(7): 1047-1061.

Ho, Y.S. \& Mckay, G. 1999. Pseudo-second order model for sorption processes. Process Biochemistry 34(5): 451-465.

Iqbaldin, M.M., Mohd Iqbaldin, M., Khudzir, I., Mohd Azlan, M., Zaidi, A., Surani, B. \& Zubri, Z. 2013. Properties of coconut shell activated carbon. Journal of Tropical Forest Science 25(4): 497-503.

Kannan, N. \& Sundaram, M.M. 2001. Kinetics and mechanism of removal of methylene blue by adsorption on various carbons-a comparative study. Dyes and Pigments 51(1): $25-40$. 
Kumar, D. \& Gaur, J.P. 2011. Chemical reaction- and particle diffusion-based kinetic modeling of metal biosorption by a Phormidium sp.-dominated cyanobacterial mat. Bioresource Technology 102(2): 633-640.

Lagergren, S. 1898. About the theory of so-called adsorption of soluble substances. Kungliga Svenska Vetenskapsakademiens Handlingar 24(4): 1-39.

Lillo-Ródenas, M.A., Lozano-Castelló, D., Cazorla-Amorós, D. \& Linares-Solano, A. 2001. Preparation of activated carbons from Spanish anthracite - II. Activation by $\mathrm{NaOH}$. Carbon 39(5): 751-759.

Lin, L., Zhai, S.R., Xiao, Z.Y., Song, Y., An, Q.D. \& Song, X.W. 2013. Dye adsorption of mesoporous activated carbons produced from $\mathrm{NaOH}-$ pretreated rice husks. Bioresource Technology 136: 437-443.

McMullan, G., Meehan, C., Conneely, A., Kirby, N., Robinson, T., Nigam, P., Banat, I.M., Marchant, R. \& Smyth, W.F. 2001. Microbial decolourisation and degradation of textile dyes. Applied Microbiology and Biotechnology 56(1-2): 81-87.

Mohan, D., Singh, K.P., Singh, G. \& Kumar, K. 2002. Removal of dyes from wastewater using flyash, a low-cost adsorbent. Industrial \& Engineering Chemistry Research 41(15): 3688-3695.

Muniandy, L., Adam, F., Mohamed, A.R. \& Ng, E.P. 2014. The synthesis and characterization of high purity mixed microporous/mesoporous activated carbon from rice husk using chemical activation with $\mathrm{NaOH}$ and $\mathrm{KOH}$. Microporous and Mesoporous Materials 197: 316-323.

Oh, G.H. \& Park, C.R. 2002. Preparation and characteristics of rice-straw-based porous carbons with high adsorption capacity. Fuel 81(3): 327-336.

Oh, G.H., Yun, C.H. \& Park, C.R. 2003. Role of KOH in the one-stage $\mathrm{KOH}$ activation of cellulosic biomass. Carbon 4(4): 180-184.

Okman, I., Karagöz, S., Tay, T. \& Erdem, M. 2014. Activated carbons from grape seeds by chemical activation with potassium carbonate and potassium hydroxide. Applied Surface Science 293: 138-142.

Patil, B.S. \& Kulkarni, K.S. 2012. Development of high surface area activated carbon from waste material. International Journal of Advanced Engineering Research and Studies I(II): 2249-8974.

Pearce, C.I., Lloyd, J.R. \& Guthrie, J.T. 2003. The removal of colour from textile wastewater using whole bacterial cells: A review. Dyes and Pigments 58: 179-196.

Rafatullah, M., Sulaiman, O., Hashim, R. \& Ahmad, A. 2010. Adsorption of methylene blue on low-cost adsorbents: A review. Journal of Hazardous Materials 177: 70-80.

Raoul, T.T.D., Gabche, A.S., Mbadcam, K.J., Ndifor-angwafor, N.G. \& Nsami, N.J. 2014. Kinetics and equilibrium studies of adsorption of phenol in aqueous solution onto activated carbon prepared from rice and coffee husks. International Journal of Engineering and Technical Research 2(10): 166-173.

Rubín, E., Rodríguez, P., Herrero, R. \& Sastre De Vicente, M.E. 2010. Adsorption of methylene blue on chemically modified algal biomass: Equilibrium, dynamic, and surface data. Journal of Chemical and Engineering Data 55(12): 5707-5714.

Rugayah, A.F., Astimar, A.A. \& Norzita, N. 2014. Preparation and characterisation of activated carbon from palm kernel shell by physical activation with steam. Journal of Oil Palm Research 26(3): 251-264.

Sajab, M.S., Chia, C.H., Zakaria, S. \& Khiew, P.S. 2013. Cationic and anionic modifications of oil palm empty fruit bunch fibers for the removal of dyes from aqueous solutions. Bioresource Technology 128: 571-577.

Sajab, M.S., Chia, C.H., Zakaria, S., Jani, S.M., Ayob, M.K., Chee, K.L., Khiew, P.S. \& Chiu, W.S. 2011. Citric acid modified kenaf core fibres for removal of methylene blue from aqueous solution. Bioresource Technology 102(15): 7237-7243.

San Miguel, G., Fowler, G.D. \& Sollars, C.J. 2003. A study of the characteristics of activated carbons produced by steam and carbon dioxide activation of waste tyre rubber. Carbon 41(5): 1009-1016.

Senthilkumaar, S., Kalaamani, P. \& Subburaam, C.V. 2006. Liquid phase adsorption of crystal violet onto activated carbon derived from male flowers of coconut tree. Journal of Hazardous Materials 136: 800-808.

Sharaf, G. \& Hassan, H. 2014. Removal of copper ions from aqueous solution using silica derived from rice straw: Comparison with activated charcoal. International Journal of Environmental Science and Technology 11(6): 1581-1590.

Sharma, S. \& Bhattacharya, A. 2017. Drinking water contamination and treatment techniques. Applied Water Science 7(3): 1043-1067.

Song, M., Jin, B., Xiao, R., Yang, L., Wu, Y., Zhong, Z. \& Huang, Y. 2013. The comparison of two activation techniques to prepare activated carbon from corn cob. Biomass and Bioenergy 48: 250-256.

Soltani, N., Bahrami, A., Pech-Canul, M.I. \& González, L.A. 2015. Review on the physicochemical treatments of rice husk for production of advanced materials. Chemical Engineering Journal 264: 899-935.

Sreńscek-Nazzal, J., Kamińska, W., Michalkiewicz, B. \& Koren, Z.C. 2013. Production, characterization and methane storage potential of $\mathrm{KOH}$-activated carbon from sugarcane molasses. Industrial Crops and Products 47: 153-159.

Sulyman, M., Namiesnik, J. \& Gierak, A. 2017. Low-cost adsorbents derived from agricultural by-products/wastes for enhancing contaminant uptakes from wastewater: A review. Polish Journal Environmental Studies 26(2): 479-510.

Sun, Q. \& Yang, L. 2003. The adsorption of basic dyes from aqueous solution on modified peat-resin particle. Water Research 37(7): 1535-1544.

Tan, I.A.W., Ahmad, A.L. \& Hameed, B.H. 2008. Adsorption of basic dye on high-surface-area activated carbon prepared from coconut husk: Equilibrium, kinetic and thermodynamic studies. Journal of Hazardous Materials 154(1-3): 337-346.

Viswanathan, B., Neel, P. \& Varadarajan, T. 2009. Methods of Activation and Specific Applications of Carbon Materials. Chennai, India: National Centre for Catalysis Research IIT Madras.

Weber, W. 1963. Kinetics of adsorption on carbon from solution. Journal of the Sanitary Engineering Division 89(2): 31-60.

Wu, M., Guo, Q. \& Fu, G. 2013. Preparation and characteristics of medicinal activated carbon powders by $\mathrm{CO}_{2}$ activation of peanut shells. Powder Technology 247: 188-196.

Wu, W., Yang, M., Feng, Q., McGrouther, K., Wang, H., Lu, H. \& Chen, Y. 2012. Chemical characterization of rice straw- 
derived biochar for soil amendment. Biomass and Bioenergy 47: 268-276.

Yu, Q., Li, M., Ning, P., Yi, H. \& Tang, X. 2014. Preparation and phosphine adsorption of activated carbon prepared from walnut shells by $\mathrm{KOH}$ chemical activation. Separation Science and Technology (Philadelphia) 49(15): 2366-2375.

Zhang, F., Ma, H., Chen, J., Li, G.D., Zhang, Y. \& Chen, J.S. 2008. Preparation and gas storage of high surface area microporous carbon derived from biomass source cornstalks. Bioresource Technology 99(11): 4803-4808.

Zhang, F., Wang, K.X., Li, G.D. \& Chen, J.S. 2009. Hierarchical porous carbon derived from rice straw for lithium ion batteries with high-rate performance. Electrochemistry Communications 11(1): 130-133.

Zhu, K., Fu, H., Zhang, J., Lv, X., Tang, J. \& Xu, X. 2012. Studies on removal of $\mathrm{NH}_{4}^{+}-\mathrm{N}$ from aqueous solution by using the activated carbons derived from rice husk. Biomass and Bioenergy 43: 18-25.

Mohamad Jani Saad, Chin Hua Chia* \& Sarani Zakaria Bioresources and Biorefinery Laboratory

Materials Science Program

Faculty of Science and Technology

Universiti Kebangsaan Malaysia

43600 UKM Bangi, Selangor Darul Ehsan

Malaysia
Mohd Saiful Sajab

Research Centre for Sustainable Process Technology

Faculty of Engineering and Built Environment

Universiti Kebangsaan Malaysia

43600 UKM Bangi, Selangor Darul Ehsan

Malaysia

Sufian Misran

Forest Research Institute of Malaysia

52100 Kepong, Selangor Darul Ehsan

Malaysia

Mohamad Jani Saad \& Wan Nazri Wan Busu

Malaysian Agriculture Research and Development Institute 43400 Serdang, Selangor Darul Ehsan Malaysia

\section{Siew Xian Chin}

ASASIpintar Program

Pusat GENIUS@Pintar Negara

Universiti Kebangsaan Malaysia

43600 UKM Bangi, Selangor Darul Ehsan

Malaysia

*Corresponding author; email: chia@ukm.edu.my

Received: 16 December 2019

Accepted: 14 May 2020 